\title{
Nutritional intakes and associated factors among tuberculosis patients: a cross- sectional study in China
}

\author{
Zhewen Ren ${ }^{1 \dagger}$, Fei Zhao ${ }^{1,2+}$, Hui Chen ${ }^{1 \dagger}$, Dongmei Hu ${ }^{1 \dagger}$, Wentao $\mathrm{Yu}^{3 \dagger}$, Xiaoli $\mathrm{Xu}^{3+}$, Dingwen Lin ${ }^{4 \dagger}$, Fuyi $\mathrm{Luo}^{5 \dagger}$,
} Yueling Fan ${ }^{6 \dagger}$, Haijun Wang ${ }^{7 \dagger}$, Jun Cheng ${ }^{1 *}$ and Liyun Zhao ${ }^{3^{*}}$

\begin{abstract}
Background: The objectives of this study were to examine nutrient intakes of tuberculosis (TB) patients and to identify their associated factors.

Methods: In this cross-sectional study, 300 adult TB patients were surveyed in two impoverished counties in China. Nutrient intakes were evaluated through two consecutive 24-h dietary recalls and compared with the Chinese Dietary Reference Intakes (DRIs) 2013. The potential socio-demographic and behavioral factors were analyzed using multivariate logistic model to identify strong influential factors.

Results: We found that mean daily energy intake was $1655.0 \mathrm{kcal}$ (SD: $619.3 \mathrm{kcal})$ and $1360.3 \mathrm{kcal}$ (SD: $552.1 \mathrm{kcal}$ ) for male and female patients, respectively. The mean daily energy intake was significantly lower than that has been recommended by DRI (i.e., 2250 and $1800 \mathrm{kcal}$ for males and females, respectively), with $87.4 \%$ of the male patients and $59.9 \%$ of female patients failed to consume adequate energy. The protein intakes were $44.6 \mathrm{~g}$ (SD: $18.2 \mathrm{~g}$ ) and $35.9 \mathrm{~g}$ (SD: $12.3 \mathrm{~g}$ ) for male and female patients, respectively, which were lower than the recommended values by DRI (i.e., 65 and $55 \mathrm{~g}$ for males and females, respectively). Most male (90.8\%) and female (58.4\%) TB patients had insufficient daily protein intake. Further analyses suggested that mean daily intakes of many micronutrients, were insufficient, while for most of patients, intakes of vitamin $E$ and sodium were sufficient. We identified that unemployment was a risk factor for low energy intake $(p<0.05)$ and out-home-eating was a protective factor for low protein intake $(p<0.01)$.

Conclusions: In impoverished areas in China, intakes of macronutrients and most micronutrients in TB patients were inadequate compared with DRIs, especially for unemployed patients and patients eating at home. These findings suggested that public health actions are needed to promote education on TB patients about significance of nutritional support, and, further interventions in TB patients' nutritional intakes are also required.
\end{abstract}

Keywords: Tuberculosis patients, Nutrient intakes, Socio-demographic factors, Behavioral factors

\footnotetext{
* Correspondence: chengjun@chinacdc.cn; liyun1964@vip.sina.com

${ }^{\dagger}$ Zhewen Ren and Fei Zhao first authors and contributed equally to this

work.

${ }^{\dagger}$ Dongmei $\mathrm{Hu}$, WentaoYu and Xiaoli Xu are contributed equally to this work.

'Dingwen Lin, Fuyi Luo, Yueling Fan, Haijun Wang are contributed equally to this work.

'National Center for Tuberculosis Control and Prevention, Chinese Center for

Disease Control and Prevention, Beijing, China

${ }^{3}$ National Institute for Nutrition and Health, Chinese Center for Disease

Control and Prevention, Beijing, China

Full list of author information is available at the end of the article
}

(c) The Author(s). 2019 Open Access This article is distributed under the terms of the Creative Commons Attribution 4.0 International License (http://creativecommons.org/licenses/by/4.0/), which permits unrestricted use, distribution, and reproduction in any medium, provided you give appropriate credit to the original author(s) and the source, provide a link to the Creative Commons license, and indicate if changes were made. The Creative Commons Public Domain Dedication waiver (http://creativecommons.org/publicdomain/zero/1.0/) applies to the data made available in this article, unless otherwise stated. 


\section{Background}

Tuberculosis (TB) is an airborne disease caused by Mycobacterium tuberculosis and is the leading cause of death from single infectious agents. According to World Health Organization (WHO), there were estimated 10.0 million people developed TB disease and 1.6 million people died from TB in 2017. China is in 2nd place among $30 \mathrm{~TB}$ high burden countries, with a reported incidence of 63 per 100,000 persons per year in 2017 [1].

The interactions between tuberculosis and malnutrition are well appreciated. TB can cause weight loss or cachexia and malnutrition can predispose to TB. On one hand, TB patient requires more energy to maintain body function that caused by increasing basal metabolic rate (BMR), leading to weight loss [2]. On the other hand, food intake may be negatively affected for TB patients due to reduction in appetite and gastrointestinal disorder [3], resulting in undernutrition. Malnutrition can further lead to impaired immune function $[4,5]$, as nutritional deficiency alters the interaction between macrophages and T-lymphocytes [6]. Moreover, although most people who get infected from TB will not manifest symptoms as their immune system manages to control the bacteria, malnourished persons are more likely to develop active TB because the infection is no longer constrained by their immune systems [7].

Assessment of nutrient intakes is critical in nutritional management of patients with TB. Enough nutrient intakes is essential for combating TB. Insufficient protein and caloric intakes can hinder the functions of some generalized host defense mechanisms that are essential for combating TB [8]. Additionally, both vitamins and minerals play important roles in immunity [9], deficiency of one or more of these nutrients will impair person's resistance to any infection [10]. Although previous studies in China suggested that protein, caloric and micronutrients intakes were inadequate in TB patients [11-13], few studies has been conducted to explore potential drivers. In this study, we 1) examined whether nutrient intakes for TB patients was sufficient in two impoverished counties in China; 2) identified the potential factors that caused the insufficient consumption of energy and protein.

\section{Methods}

\section{Study context}

This cross-sectional study was undertaken as part of the project "Investigation of nutrition and diet of patients with pulmonary tuberculosis in poor areas in China" supported by the World Health Organization Regional Office in the Western Pacific. It was conducted from November 2015 to April 2017 in two counties, Lingyun county in Guangxi province and Lin county in Shanxi Province. These two counties were national impoverished counties, and did good job in TB management. TB case notification rates in
2016 were 106.97 per 100,000 and 63.16 per 100,000 in Lingyun county and Lin county, respectively.

\section{Participants}

We focused our study on adult patients (age $\geq 18$ years) with active TB who were registered in Tuberculosis management information system from Nov 1st, 2015 through May $11^{\text {th }}$, 2017. Patients with extrapulmonary tuberculosis, and those aged 18 years and below or with severe complications were not eligible for the study. Pregnant or breast-feeding women, and those who declined to sign the consent form were also excluded.

\section{Sample size}

As BMI is commonly used in nutrition assessment, we applied the prevalence of $\mathrm{BMI}<18.5$ which is also defined as malnutrition [14] in determining sample size. We assumed that the prevalence of malnutrition in the general population in poor areas and TB patients would be $6.7 \%$ [15] and $25.0 \%$ [2], respectively, and the required sample size was calculated to detect difference in the two proportions. The probability of a type I error was set at 0.05 , the power of the study was estimated at $90 \%$ and the design effect was set at 1, determining a sample size of TB patients was 77 per study site. Considering participants' refusal, we expanded the sample size to 150 per study site, and the final sample size of TB patients was 300 totally.

\section{Socio-demographic and behavioral factors}

Data for associated factors were taken from a questionnaire, including socio-demographic attributes (age, gender, education level, marital status, occupation and household income level) and behavioral variables (alcohol consumption, smoking status and eating out-of-home).

In line with Chinese Dietary Reference Intakes (DRIs) 2013 [16], we categorized patients' ages into 3 groups: 18-49 years, 50-64 years, 65 years and above to facilitate comparisons. Educational level was classified into primary school and below, junior middle school and above. Household income level was proxied as annual household income and was grouped into $<¥ 20,000$, $¥ 20,000$ $¥ 40,000$, and $\geq ¥ 40,000$ [17]. Alcohol consumption was surveyed as drinking wine, beer and Chinese spirit now or ever. A smoker was defined as smoking now or smoking previously but have stopped smoking in the evaluation period. Eating out-of-home was defined as eating at least one meal away from one's own home or their residents' home during the survey [18]. Severity of TB was grouped into two categories based on chest $\mathrm{x}$-ray. Specifically, if the lesion was confined to two lung fields then it was defined as mild. If the lesion covered more than two lung fields or there were cavities, it was defined as severe [19]. 
Table 1 Socio-demographic and behavioral characteristics for 300 TB patients

\begin{tabular}{|c|c|c|c|}
\hline \multirow{2}{*}{$\frac{\text { Characteristics }}{\text { Socio-demographic factors }}$} & & $\mathrm{N}$ & N\% \\
\hline & & & \\
\hline \multirow[t]{4}{*}{ Age group } & $18-49$ & 161 & 53.7 \\
\hline & $50-64$ & 86 & 28.7 \\
\hline & $\geq 65$ & 53 & 17.7 \\
\hline & Mean $( \pm S D)$ & $\begin{array}{l}45.5 \\
18.7)\end{array}$ & \\
\hline \multirow[t]{2}{*}{ Gender } & Male & 206 & 68.7 \\
\hline & Female & 94 & 31.3 \\
\hline \multirow[t]{2}{*}{ Education } & Primary school and below & 161 & 53.7 \\
\hline & Junior middle school and above & 139 & 46.3 \\
\hline \multirow[t]{2}{*}{ Marital status } & Married & 209 & 69.7 \\
\hline & Other marital status & 91 & 30.3 \\
\hline \multirow[t]{2}{*}{ Occupation } & Employed & 178 & 59.3 \\
\hline & Unemployed & 122 & 40.7 \\
\hline \multirow[t]{5}{*}{ Annual household income ${ }^{a}$} & $<20,000$ & 136 & 45.3 \\
\hline & $20,000-40,000$ & 79 & 26.3 \\
\hline & $\geq 40,000$ & 20 & 6.7 \\
\hline & Refusal or unknown & 65 & 9.7 \\
\hline & Mean $( \pm$ SD) & \multicolumn{2}{|c|}{$\begin{array}{l}18,203.1 \\
( \pm 17 \\
622.2)\end{array}$} \\
\hline \multicolumn{4}{|l|}{ Behavioral factors } \\
\hline \multirow[t]{2}{*}{ Alcohol consumption } & Yes & 119 & 39.7 \\
\hline & No & 181 & 60.3 \\
\hline \multirow[t]{2}{*}{ Smoking status } & Smoker & 140 & 46.7 \\
\hline & Non-smoker & 160 & 53.3 \\
\hline \multirow[t]{2}{*}{ Eating out-of-home } & Yes & 58 & 19.3 \\
\hline & No & 242 & 80.7 \\
\hline
\end{tabular}

${ }^{a} 65$ patients who refused or with missing data were excluded from this analysis

\section{Assessment of nutrient intake}

Trained staffs performed face-to-face interviews for each participant to obtain dietary intake data through a 2-day 24-h dietary recall (24hdr) questionnaire, which was adapted from the method of 3-day 24hdr [20]. Participants were instructed to record all food intake at home and away from home in the previous 2 days (one weekday and one weekend day). Consumptions of condiments were also recorded through a questionnaire. All questionnaires were completed after the patient registering in Tuberculosis management information system and before anti-tuberculosis treatment.

Total energy, four macronutrients and sixteen micronutrients were evaluated. Nutrient intakes of each patient were converted to calories, weight of protein and weight of micronutrients based on Chinese Food Composition Tables (CFCT) 2004 [21].
To evaluate whether the patients' nutrients were sufficient, we compared mean daily nutrient intakes of TB patients to Recommended Nutrient Intakes (RNIs) and Adequate Intakes (AIs) by Chinese dietary reference intakes (DRIs) 2013. Recommended Nutrient Intakes is an estimate of the amount of a nutrient that meets the requirements of most people (97-98\%) within a specific physiological group (sex, age, body size, physical activity, type of diet). Adequate Intakes means a recommended intake value based on observed or experimentally determined approximations or estimates of nutrient intake by a group (or groups) of healthy people [16].

\section{Statistical analysis}

Data of daily nutrient intakes were presented as means \pm standard deviation (SD). As dietary recommendations are different for men and women, we compared TB patients' daily nutrient intakes with DRIs by gender. Since proteincalorie malnutrition (PCM) is the most common form of undernutrition in TB patients, we only examined factors related to insufficient energy and protein intakes. Univariate logistic regression analysis was used to identify potential risk factors associated with inadequate energy and protein intakes in $300 \mathrm{~TB}$ patients. Age, gender, county and severity of TB were considered to be possible confounders in the multiple logistic regression model with stepwise selection. Patients were classified into two groups: below RNI/AI and above RNI/AI. A P-value of less than 0.05 was considered statistically significant. All analyses were performed using SAS 9.4 (SAS Institute Inc., Cary, NC, USA).

\section{Quality control}

The study was carried out on the basis of China Health and Nutrition Survey (CHNS) 2015, from which the investigating method and tool were used in our study. All on-site investigations were carried out by the county-level CDC and interviewers were trained with a standard protocol. Data was checked for completeness and accuracy on the day of investigation and sampled by provincial CDC for verification later. All data was double-entered into a database specially designed for this project.

\section{Results}

\section{Characteristics of the subjects}

All TB patients registered from Nov 1st, 2015 to May 11th, 2017 in Lin county were included in our study, while less than $40 \%$ of notified TB patients in Lingyun county have participated in this study.

The majority (53.7\%) of TB patients aged between 18 and 49 , with the mean age being 45.5 years old (standard deviation (SD):18.7). More than half (68.7\%) of them were males. Most TB patients were married, employed 
Table 2 Daily energy and macronutrient intakes of TB patients compared with DRIs

\begin{tabular}{|c|c|c|c|c|c|c|}
\hline \multirow{2}{*}{$\begin{array}{l}\text { Energy and } \\
\text { macronutrient intakes }\end{array}$} & \multicolumn{3}{|c|}{ Males $(n=206)$} & \multicolumn{3}{|c|}{ Females $(n=94)$} \\
\hline & $\mathrm{RNI} / \mathrm{Al}$ & Mean (SD) & Below RNI/AI(\%) & $\mathrm{RNI} / \mathrm{Al}$ & Mean (SD) & Below RNI/Al(\%) \\
\hline Calories (Kcal) & 2250 & $1655.0(619.3)$ & $180(87.4)$ & 1800 & $1360.3(552.1)$ & $78(83.0)$ \\
\hline Total Protein (g) & 65 & $44.6(18.2)$ & $187(90.8)$ & 55 & $35.9(12.3)$ & $86(91.5)$ \\
\hline Total Fat (g) & - & $73.0(50.5)$ & - & - & $68.9(48.3)$ & - \\
\hline Total Carbohydrates (g) & - & $212.1(117.2)$ & - & - & $154.8(58.0)$ & - \\
\hline Total fiber (g) & - & $7.6(4.3)$ & - & - & $5.7(2.6)$ & - \\
\hline
\end{tabular}

and didn't attend junior middle school and above, with annual household income less than ¥20, 000. Only 39.7\% of them consumed alcohol, while $46.7 \%$ of them were smokers (Table 1).

\section{Daily energy and nutrient intake}

The average daily energy was $1655.0 \mathrm{kcal}$ (SD: $619.3 \mathrm{kcal}$ ) and $1360.3 \mathrm{kcal}$ (SD: $552.1 \mathrm{kcal}$ ) for males and females, respectively, which were significantly lower than recommended daily energy intake by DRIs (i.e., $2250 \mathrm{kcal}$ and $1800 \mathrm{kcal}$ for males and females). The protein intake was $44.6 \mathrm{~g}$ (SD: $18.2 \mathrm{~g}$ ) and $35.9 \mathrm{~g}$ (SD: $12.3 \mathrm{~g}$ ) for male and female TB patients, respectively. The protein daily intakes for our surveyed TB patients was significantly lower than daily protein intakes that were recommended by DRIs, which were $65 \mathrm{~g}$ and $55 \mathrm{~g}$ for males and females, respectively (Table 2). Our results also indicated that the male patients were more likely subjected to malnutrition. For example, percentages of male patients that had daily intakes below RNI/AI were 87.4 and $90.8 \%$ for daily energy intakes and protein intakes, respectively. Percentages for male patients were 59.9 and $58.4 \%$ for daily energy and protein intakes, respectively. As for micronutrients, for male TB patients, the mean daily intakes of retinol, niacin, vitamin E, sodium, iron, Manganese, copper and Phosphorus were higher than RNI/ AI, while calcium, i.e., $216.3 \mathrm{mg}$, intake was severely less than RNI/AI ( $800 \mathrm{mg}$ ) (Table 3). For the female patients, the mean daily intakes of vitamin E, copper and sodium were higher than RNI/AI. However, the intakes of riboflavin, potassium and calcium were severely inadequate.

\section{Factors associated with low energy and low protein intakes in $\mathbf{3 0 0}$ TB patients}

Our univariate analyses suggested that employment status influenced energy intake, with lower energy consumption was found for the patients that were unemployed (Table 4). Furthermore, annual household income was another factor that affected daily energy intakes, for the patients whose annual salary was more than $¥ 40,000$ tended to

Table 3 Daily micronutrient intakes of TB patients compared with DRIs

\begin{tabular}{|c|c|c|c|c|c|c|}
\hline \multirow{2}{*}{$\begin{array}{l}\text { Micronutrient } \\
\text { intakes }\end{array}$} & \multicolumn{3}{|c|}{ Males $(n=206)$} & \multicolumn{3}{|c|}{ Females $(n=94)$} \\
\hline & $\mathrm{RNI} / \mathrm{Al}$ & Mean (SD) & Below RNI/AI(\%) & $\mathrm{RNI} / \mathrm{Al}$ & Mean (SD) & Below RNI/Al(\%) \\
\hline Retinol $(\mu \mathrm{g})$ & 800 & 807.5 (994.0) & $135(65.5)$ & 700 & $603.9(626.7)$ & $68(72.3)$ \\
\hline Thiamin (mg) & 1.4 & $0.9(0.5)$ & $180(87.4)$ & 1.2 & $0.7(0.3)$ & 88 (93.6) \\
\hline Riboflavin (mg) & 1.4 & $0.6(0.3)$ & $203(98.5)$ & 1.2 & $0.5(0.2)$ & $94(100)$ \\
\hline Niacin (mg) & 12 & $12.6(5.3)$ & 94 (45.6) & 15 & $10.3(4.7)$ & $78(83.0)$ \\
\hline Vitamin E (mg) & 14 & $53.6(39.6)$ & $13(6.3)$ & 14 & $57.1(40.0)$ & $4(4.3)$ \\
\hline Vitamin C (mg) & 100 & $96.6(75.3)$ & $130(63.1)$ & 100 & $70.2(55.8)$ & $74(78.7)$ \\
\hline Potassium (mg) & 2000 & $1309.2(636.7)$ & $180(87.4)$ & 2000 & 1011.7 (351.0) & $94(100)$ \\
\hline Sodium (mg) & 1500 & 2204.4 (1204.8) & 67 (35.5) & 1500 & $2054.5(1123.4)$ & $28(29.8)$ \\
\hline Calcium (mg) & 800 & $216.3(126.2)$ & 205 (99.5) & 800 & $176.9(86.5)$ & $94(100)$ \\
\hline Magnesium (mg) & 330 & $221.0(112.0)$ & $174(84.5)$ & 330 & $166.0(56.6)$ & $92(97.9)$ \\
\hline Iron (mg) & 12 & $14.2(6.8)$ & $86(41.8)$ & 20 & $10.8(3.7)$ & $92(97.9)$ \\
\hline Manganese (mg) & 4.5 & $4.7(2.3)$ & $126(61.2)$ & 4.5 & $3.5(1.3)$ & $83(88.3)$ \\
\hline Zinc (mg) & 12.5 & $5.5(2.9)$ & $196(95.2)$ & 7.5 & $4.1(1.5)$ & $90(95.7)$ \\
\hline Copper (mg) & 0.8 & $1.2(1.2)$ & $72(35.0)$ & 0.8 & $0.9(0.3)$ & $53(56.4)$ \\
\hline Phosphorus (mg) & 720 & 745.7 (382.1) & $116(56.3)$ & 720 & $571.8(173.0)$ & $74(78.7)$ \\
\hline Selenium $(\mu \mathrm{g})$ & 60 & $26.3(15.3)$ & $200(97.1)$ & 60 & $20.2(10.2)$ & 93 (98.9) \\
\hline
\end{tabular}


Table 4 Factors associated with low energy and low protein intakes using univariate regression analysis in 300 TB patients

\begin{tabular}{|c|c|c|c|c|c|}
\hline \multirow[t]{2}{*}{ Associated factors } & & \multicolumn{2}{|l|}{ Energy } & \multicolumn{2}{|l|}{ Protein } \\
\hline & & OR $(95 \% \mathrm{Cl})$ & $P$ & $\mathrm{OR}(95 \% \mathrm{Cl})$ & $P$ \\
\hline \multicolumn{6}{|l|}{ Socio-demographic factors } \\
\hline \multirow[t]{3}{*}{ Age } & $18-49$ & 1.0 & & 1.0 & \\
\hline & $50-64$ & $1.032(0.498,2.138)$ & 0.9319 & $2.039(0.730,5.698)$ & 0.1741 \\
\hline & $\geq 65$ & $2.252(0.746,6.797)$ & 0.1499 & $1.542(0.498,4.778)$ & 0.4530 \\
\hline \multirow[t]{2}{*}{ Area } & Lin county & 1.0 & & 1.0 & \\
\hline & Linyun county & $0.639(0.329,1.240)$ & 0.1856 & $1.509(0.676,3.369)$ & 0.3158 \\
\hline \multirow[t]{2}{*}{ Gender } & male & 1.0 & & 1.0 & \\
\hline & female & $0.704(0.358,1.386)$ & 0.3098 & $1.092(0.460,2.593)$ & 0.8415 \\
\hline \multirow[t]{2}{*}{ Severity } & mild & 1.0 & & 1.0 & \\
\hline & severe & $0.851(0.425,1.704)$ & 0.6486 & $0.859(0.370,1.911)$ & 0.7224 \\
\hline \multirow[t]{2}{*}{ Education } & Primary school and below & 1.0 & & 1.0 & \\
\hline & Junior middle school and above & $1.503(0.547,2.207)$ & 0.8780 & $0.923(0.418,2.037)$ & 0.8429 \\
\hline \multirow[t]{2}{*}{ Marriage } & Married & 1.0 & & 1.0 & \\
\hline & unmarried & $1.708(0.781,3.735)$ & 0.1797 & $0.859(0.370,1.991)$ & 0.7224 \\
\hline \multirow[t]{2}{*}{ Occupation } & Employed & 1.0 & & 1.0 & \\
\hline & Unemployed & $3.364(1.499,7.550)$ & 0.0033 & $1.412(0.612,3.257)$ & 0.4181 \\
\hline \multirow[t]{3}{*}{ Annual household income } & $<20,000$ & 1.0 & & 1.0 & \\
\hline & $20,000-40,000$ & $0.766(0.333,1.762)$ & 0.5311 & $0.905(0.336,2.438)$ & 0.8437 \\
\hline & $\geq 40,000$ & $0.289(0.097,0.866)$ & 0.0266 & $0.499(0.126,1.969)$ & 0.3207 \\
\hline \multicolumn{6}{|l|}{ Behaviroral factors } \\
\hline \multirow[t]{2}{*}{ Alcohol consumption } & No & 1.0 & & 1.0 & \\
\hline & Yes & $1.372(0.690,2.731)$ & 0.3670 & $1.350(0.585,3.113)$ & 0.4821 \\
\hline \multirow[t]{2}{*}{ Smoking status } & Non-smoker & 1.0 & & 1.0 & \\
\hline & Smoker & $0.766(0.399,1.472)$ & 0.4243 & $0.482(0.213,1.092)$ & 0.0802 \\
\hline \multirow[t]{2}{*}{ Eating out-of-home } & No & 1.0 & & 1.0 & \\
\hline & Yes & $0.628(0.294,1.228)$ & 0.2280 & $0.302(0.132,0.693)$ & 0.0047 \\
\hline
\end{tabular}

Note: Intake above RNI/Al was assigned as 0 , intake below RNI/Al was assigned as 1 . The sample size of analysis of annual household income was 235

have enough energy intakes. In multivariate analysis (Table 5), after adjusting for other factors, unemployed participants were more likely to have low energy intake (OR: 3.542; 95\%CI: $1.471,8.530)(p<0.01)$. Meanwhile, lower protein intake was associated with eating at home. The possibility of low protein intake for people eating outof-home was much lower than those eating at home (OR: 0.328; 95\% CI: 0.133, 0.809) $(p<0.05)$.

\section{Discussion}

Our study demonstrated that intakes of both macronutrients and selected micronutrients were inadequate for most TB patients, regardless of their gender. Proteincalorie malnutrition (PCM), characterized by inadequate intakes of both protein and total calories [8], was common in TB patients. This finding was consistent with previous studies in China [11-13]. PCM can reduce effectiveness of some components that play important roles in cellmediated immunity [8].

We found that mean daily intakes of many micronutrients were below RNI/AI, especially calcium. One potential explanation is that TB patients do not consume enough fish, shrimp and dairy products [22], which are all calcium-rich food. Calcium plays an important role in the recovery of $\mathrm{TB}$ as the calcification of lesions requires a large amount of calcium, thus calcium deficiency can lead to delayed recovery [12]. Our results suggested that over 95\% TB patients didn't have adequate intakes of essential micronutrients such as riboflavin, zinc and selenium. Riboflavin is associated with the metabolisms of iron and niacin and its deficiency will compromise oxidant defense mechanisms [23]. Zinc has an essential role in vitamin A metabolism and supplementation of zinc will increase immune function in TB patients [24]. Selenium is reported to have an important function in maintaining the 
Table 5 Factors associated with low energy and low protein intakes using multivariate regression analysis in 300 TB patients

\begin{tabular}{|c|c|c|c|c|}
\hline \multicolumn{3}{|c|}{ Associated factors } & \multirow{2}{*}{$\begin{array}{l}\mathrm{OR}(95 \% \mathrm{Cl}) \\
1.0\end{array}$} & \multirow[t]{2}{*}{$P$} \\
\hline Energy & Age & $18-49$ & & \\
\hline & & $50-64$ & $1.010(0.452,2.260)$ & 0.9800 \\
\hline & & $\geq 65$ & $1.916(0.560,6.555)$ & 0.3002 \\
\hline & Gender & Male & 1.0 & \\
\hline & & female & $0.512(0.246,1.067)$ & 0.0741 \\
\hline & Area & Lin county & 1.0 & \\
\hline & & Linyun county & $0.631(0.286,1.394)$ & 0.2550 \\
\hline & Severity & mild & 1.0 & \\
\hline & & severe & $1.192(0.546,2.605)$ & 0.6595 \\
\hline & Occupation & Employed & 1.0 & \\
\hline & & Unemployed & $3.542(1.471,8.530)$ & 0.0048 \\
\hline & Annual household & $<20,000$ & 1.0 & \\
\hline & & $20,000-40,000$ & $1.242(0.536,2.877)$ & 0.6132 \\
\hline & & $\geq 40,000$ & $0.366(0.115,1.163)$ & 0.0885 \\
\hline \multirow[t]{11}{*}{ Protein } & Age & $18-49$ & 1.0 & \\
\hline & & $50-64$ & $1.460(0.490,4.353)$ & 0.4927 \\
\hline & & $\geq 65$ & $0.985(0.285,3.401)$ & 0.9813 \\
\hline & Gender & Male & 1.0 & \\
\hline & & female & $1.133(0.468,2.741)$ & 0.7817 \\
\hline & Area & Lin county & 1.0 & \\
\hline & & Linyun county & $1.284(0.489,3.370)$ & 0.6122 \\
\hline & Severity & mild & 1.0 & \\
\hline & & severe & $0.690(0.266,1.792)$ & 0.4461 \\
\hline & Eating out-of- & No & 1.0 & \\
\hline & & Yes & $0.328(0.133,0.809)$ & 0.0155 \\
\hline
\end{tabular}

Note: Intake above RNI/AI was assigned as 0 , intake below RNI/Al was assigned as 1 . The sample size of analysis of annual household income was 235

immune process and is beneficial for the clearance of mycobacteria [25]. However, sodium consumption was higher than RNI/AI in TB patients. Researches conducted in other populations [26-28] in China also showed that high sodium consumption remained a public health problem. Nevertheless, the quality of diet seemed to be improved, as the mean daily intake of vitamin $\mathrm{E}$ was much higher than RNI/AI and the values that were reported in previous studies [11-13].

Furthermore, we discerned that eating out-of-home was related to higher intake of protein. Relevant studies conducted among other populations in China [29-31] also demonstrated that there was an increase in protein intake while eating out-of-home. The reason for this phenomenon may be that people tend to choose food with better tastes and higher nutritional values when they eat away from home [30]. Additionally, eating outof-home has more frequently been associated with higher socioeconomic status (measured by higher education level and household income) [29, 32, 33], as people in higher socioeconomic status are more likely to afford frequent away-from-home food consumption. We also discovered that the inadequate energy intake was significantly higher among unemployed TB patients, which is consistent with studies conducted in other countries [34, 35]. This is most likely because that the patients with low socioeconomic status may not be able to afford nutritious food.

Malnutrition can also have a negative impact on the treatment of TB. Malnutrition will reduce the level of protein in the patient's body, and thus delayed the recovery of lesions. This is probably because sufficient protein not only can promote the recovery of lesions during the treatment, but also can increase the number of antituberculosis drug carriers in the treatment, therefore, concentration of anti-tuberculosis drugs in the blood will rise, promoting sputum conversion [36]. A study in China showed that $56 \%$ of patients' sputum culture were negative after 20 days of treatment in the nutritional support group, which was significantly higher than $28 \%$ in the general treatment group [37].

\section{Strengths and limitations}

Our study initiated in examining factors associated with TB patients' nutrient intake and was also the first study in China to compare nutrient intakes of TB patients with the latest Chinese Dietary Reference Intakes (DRIs) 2013. However, there are still some limitations in our study. Firstly, the 24hdr method has its own shortcomings. Reliance on the memory of participants and recall bias could result in an underestimation of nutrient intakes [38]. Secondly, considering that more times we interviewed, less cooperate would TB patients be because they may be worried about being discriminated against, so we took the 2day 24hdrs method instead of the commonly used 3-day 24hdrs, but the reliability may decrease. A study conducted among African American youth showed that reliability estimates for 3-day 24 hdrs ranged from 27 to $62 \%$, while, for 2-day 24hdrs, it ranged from 19 to 52\% [39]. And, when measuring the consumption of condiments, we didn't take the household weighing method commonly used in nutrition survey. Thirdly, we hope to enroll all eligible TB patients in these two counties notified from Nov 1st, 2015 to May 11th, 2017. All notified TB patients in Lin county were included in our study, while TB patients enrolled in our study accounted for less than $40 \%$ of all notified TB patients in Lingyun county during that period. Moreover, we measured socioeconomic status of $\mathrm{TB}$ patients only by annual household income and this was not enough to capture the economic disparities. All of these may result in that our findings could not be generalized to all the local people. 


\section{Conclusions}

In this study, we showed that in poor areas of China, the intakes of macronutrients and most micronutrients for TB patients were lower than DRIs, especially for those unemployed and eating at home. To reach effective treatments for TB patients, our study calls for promotion of awareness of significance of nutritional support in treatment process. In some cases, interventions in $\mathrm{TB}$ patients' nutritional intakes are also required. Most importantly, the government should provide financial support for the patient so that they can afford enough food supplies.

\section{Abbreviations}

24hdr: 24-h dietary recall; Al: Adequate Intake; BMR: basal metabolic rate; CDC: Center for disease control and prevention; CFCT: Chinese Food Composition Tables; CHNS: China Health and Nutrition Survey; DRIs: Dietary Recommended Intakes; PCM: Protein-calorie malnutrition; RNI: Recommend Nutrient Intake; SD: Standard deviation; TB: tuberculosis; WHO: World Health Organization

\section{Acknowledgements}

We appreciate technical input provided by Dr. Nobuyuki Nishikiori throughout the design and implementation of the study. We would like to acknowledge the staff in Shanxi and Guangxi provincial CDCs, and local CDCs in undertaking this survey.

\section{Authors' contributions}

ZWR: analyzed the data, completed statistical analysis and wrote the initial draft of the manuscript. FZ: conceived the research idea, conducted the data collection. HC and DMH: made contributions to data analysis. WTY and XLX: supervises the data collection and analysis. DWL, FYL, YLF and HJW: participated in the implementation of the study. JC and LYZ: designed the study and contributed to the protocol conception. All authors' read and approved the final manuscript.

\section{Funding}

The study was funded by the WHO Regional Office in the Western Pacific.

\section{Availability of data and materials}

The datasets used or analyzed during the current study are available from the corresponding author on reasonable request.

\section{Ethics approval and consent to participate}

The present study protocol was approved by the China CDC Institutional Ethics Review Board (NO. 201532) and The Ethic Review Committee of the WHO Regional Office in the Western Pacific (2015.22.CHN.3.STB). All those agreed to participate in the survey had to provide informed consent.

\section{Consent for publication}

Not applicable.

\section{Competing interests}

The authors declare that they have no competing interests.

\section{Author details}

${ }^{1}$ National Center for Tuberculosis Control and Prevention, Chinese Center for Disease Control and Prevention, Beijing, China. ${ }^{2}$ Clinical Trial And Research Center, Beijing Hospital, Beijing, China. ${ }^{3}$ National Institute for Nutrition and Health, Chinese Center for Disease Control and Prevention, Beijing, China. ${ }^{4}$ Guangxi Zhuang Autonomous Region Center for Disease Control and Prevention, Nanning, China. ${ }^{5}$ Linyun County Center for Disease Prevention and Control, Baise, China. ${ }^{6}$ Shanxi Provincial Center for Disease Control and Prevention, Taiyuan, China. ${ }^{7}$ Lin County People's Hospital, Lvliang, China.
Received: 14 April 2019 Accepted: 16 September 2019

Published online: 29 October 2019

\section{References}

1. World Health Organization. Global tuberculosis report 2018. Geneva: World Health Organization; 2018.

2. World Health Organization. Guideline: nutritional care and support for patients with tuberculosis. Genava: World Helath Organization; 2013.

3. Fang Z, Feng L. Analysis of anemia caused by tuberculosis. Acta Academiae Medicinae Zunyi. 2002;25(5):441.

4. Perronne C. Tuberculosis, HIV infection, and malnutrition: an infernal trio in Central Africa. Nutr. 1999;15(4):321-2.

5. Derek C. Macallan. Malnutrition in tuberculosis. Diagn Microbiol Infect Dis. 1999;34(2):153-7.

6. Chan J, Tanaka K, Mannion C, Carroll D, Tsang M, Xing Y, et al. Effects of protein calorie malnutrition on mice infected with BCG. J Nutr Immunol. 1997:5(1):11-9.

7. Grobler L, Nagpal S, Sudarsanam TD, Sinclair D. Nutritional supplements for people being treated for active tuberculosis: : a technical summary. Cochrane Database Syst Rev. 2018;108(1):16-8.

8. Koethe JR, von Reyn CF. Protein-calorie malnutrition, macronutrient supplements, and tuberculosis. Int J Tuberc Lung Dis. 2016;20(7):857-64.

9. Karyadi E, Schultink W, Nelwan RH, Gross R, Amin Z, Dolmans WM, et al. Poor micronutrient status of active pulmonary tuberculosis patients in Indonesia. J Nutr. 2000;130(12):2953-8.

10. Crowle AJ, Ross EJ. Inhibition by retinoic acid of multiplication of virulent tubercle bacilli in cultured human macrophages. Infect Immunity. 1989; 57(3):840-4.

11. Su LP, Lian SQ, Li XG, Hu YF, Wang QZ, Wang Y, et al. Investigation of tuberculosis Patients' food diversification levels and nutrients intake in Wuwei City. Progress Modern Biomed. 2013;13(33):6566-71.

12. Li CK, Wang QZ, Han XX, Zhao J, Wang YW, Liu ZQ, et al. Comparative analysis of nutrient intake and food diversification levels of tuberculosis patients and healthy population in rural areas. Food Nutr China. 2012; 18(05):74-8.

13. Wang YK, Han XX, Wang QZ, Ma AG, Chen L, Zhao SL, et al. Dietary diversity score and nutrient intakes of tuberculosis patients. Food Nutr China. 2017; 17(1):71-7.

14. BMI classification-Global Database on Body Mass Index [Internet]. World Health Organization. 2015. Available from: http://apps.who.int/bmi/index. jsp?introP?age=intro_3.html. Accessed 12 Oct 2018.

15. National Health and Family Planning Commission of the People's Republic of China. Report of nutrition and chronic diseases in Chinese residents (2015). Beijing: People's Medical Press; 2015.

16. Chinese Nutrition Society. Chinese dietary reference intakes handbook (2013),1sted. Beijing: China Standards Press; 2014.

17. Liang HM, Fan YL, Wang CP, Fan LY, Gao JW. Investigations and analysis of diet and nutrition of tuberculosis patients in poor areas in Shanxi province. Chin Remedies Clin. 2018;18(10):1702-4.

18. Wang Z, Xiang XS, Li XQ, He YN, Yang YX. Survey on diet and nutrition intake for customers from out-home eating in Beijing. J Hygiene Res. 2015; 02:232-6+41.

19. Wang $L$, Cai $Y-Y$, Cheng Q- L, Hu Y, Xiao H-p. Imbalance of Th1/Th2 cytokines in patients with pulmonary tuberculosis. Chin J Tuberculosis Respiratory Dis. 2002;25(9):535-7.

20. Fiorentino M, Landais E, Bastard G, Carriquiry A, Wieringa FT, Berger J. Nutrient intake is insufficient among Senegalese Urban School children and adolescents: results from two $24 \mathrm{~h}$ recalls in state primary schools in Dakar. Nutrients. 2016:8(10):650.

21. National Institute for Nutrition and Food Safety of Chinese Center for Disease Control and Prevention. Chinese food composition table 2004. Beijing: Pecking University Medical Press; 2005.

22. Shi GS, Chen J, Xia YY, Zhao F, Zhang CY, Hu DM, et al. Investigation and analysis on dietary and nutritional status of 336 new bacteriologically confirmed tuberculosis patients. Chin J Antituberculosis. 2017;39(5):488-94.

23. Pinto JT, Zempleni J. Riboflavin. Adv Nutr. 2016;7(5):973-5.

24. Gupta KB, Gupta R, Atreja A, Verma M, Vishvkarma S. Tuberculosis and nutrition. Lung India. 2009:26(1):9-16.

25. Choi R, Jeong BH, Koh WJ, Lee SY. Recommendations for optimizing tuberculosis treatment: therapeutic drug monitoring, pharmacogenetics, and nutritional status considerations. Ann Lab Med. 2017;37(2):97-107. 
26. Zhang Y, Zhou H, Perkins A, Wang Y, Sun J. Maternal dietary nutrient intake and its association with preterm birth: a case-control study in Beijing, China. Nutrients. 2017;9(3):1778-86.

27. Liu FL, Zhang YM, Pares GV, Reidy KC, Zhao WZ, Zhao A, et al. Nutrient intakes of pregnant women and their associated factors in eight cities of China: a cross-sectional study. Chin Med J. 2015;128(13):1778-86.

28. Yin S. Chinese women's nutrition and health (women of childbearing age, pregnant women and lactating mother): Chinese nutrition and health survey in 2002. Beijing: People's Medical Publishing House; 2008.

29. Zhang J, Luo B, Wang Y, Zhu Z, Wang Z, He X, et al. Eating out-of-home in adult residents in Shanghai and the nutritional differences among dining places. Nutrients. 2018;10(7):951.

30. Cao K-k. The study on diet intakes and nutritional status of out-of-home eating residents and the association between eating out of home and overweight/obesity [master]: Chinese Center for Disease Prevention and Control; 2014

31. Du W-w. Dynamics of eating away from home and association with nutritional outcomes among Chinese adults [PHD]: Chinese center for disease prevention and control; 2014

32. Mills S, Adams J, Wrieden W, White M, Brown H. Sociodemographic characteristics and frequency of consuming home-cooked meals and meals from out-of-home sources: cross-sectional analysis of a population-based cohort study. Public Health Nutr. 2018;21(12):2255-66.

33. Cavalcante JB, Moreira TMV, Mota CDC, Pontes CR, Bezerra IN. Energy and nutrient intake according to away-from-home food consumption in the northeast region: an analysis of the 2008-2009 National Dietary Survey. Revista Bras Epidemiol. 2017;20(1):115-23.

34. Oldewage-Theron WH, Kruger R, Egal AA. Socio-economic variables and nutrient adequacy of women in the Vaal region of South Africa. Ecol Food Nutr. 2014:53(5):514-27.

35. Livingstone KM, Olstad DL. Socioeconomic inequities in diet quality and nutrient intakes among Australian adults: findings from a nationally representative cross-sectional study. Nutrients. 2017;9(10):1092.

36. Duan M-m, Chen X-r. Observation on the clinical effect of nutrition support for treatment of severe pulmonary tuberculosis. Modern Prevent Med. 2017; 44(24):4525-7.

37. Xu Y-I. Investigation on the nutritional status and nutritional therapy in 398 patients with pulmonary tuberculosis. J Chin Antituberculosis Assoc. 2008; 30(4):335-7.

38. Castell GS, Serra-Majem L, Ribas-Barba L. What and how much do we eat? 24-hour dietary recall method. Nutricion Hospitalaria. 2015;31(3):46-8.

39. George SMS, Van Horn ML, Lawman HG, Wilson DK. Reliability of 24-hour dietary recalls as a measure of diet in African-American youth. J Acad Nutr Diet. 2016;116(10):1551-9.

\section{Publisher's Note}

Springer Nature remains neutral with regard to jurisdictional claims in published maps and institutional affiliations.

Ready to submit your research? Choose BMC and benefit from:

- fast, convenient online submission

- thorough peer review by experienced researchers in your field

- rapid publication on acceptance

- support for research data, including large and complex data types

- gold Open Access which fosters wider collaboration and increased citations

- maximum visibility for your research: over $100 \mathrm{M}$ website views per year

At $\mathrm{BMC}$, research is always in progress.

Learn more biomedcentral.com/submissions 